\title{
The Impact of Information Sharing and Quality Assurance on Customer Service at UAE Banking Sector
}

\author{
Abdulsattar Al Ali \\ Dr. Kanayalal Rania Inc., Canada, asmalali.alali@gmail.com
}

\begin{abstract}
In the present competitive market, information sharing and quality assurance are both needed for client support. This relationship was set up through a quantitative examination study. The information was gathered utilizing the poll strategy, and the discoveries uncovered that, despite options, banks are continually enticed to bundle item contributions to draw in clients. This appeal stems exclusively from the arrangement of excellent administrations. At last, ideas are made for additional improvement to remain competitive in the monetary market.
\end{abstract}

Keywords: Quality assurance, information sharing, customer services, banking industry

\section{Introduction}

Information sharing has become a vital part of successful organizations. The exchange of data between technologies, people, and within an organization or outside organization is called information sharing [1]. Information sharing can be divided into different types, such as when an individual shares some information, for example, on social media platforms (Facebook, Instagram, YouTube, etc.). Another type can be the information shared by an organization through different methods, for example, using RSS feed to share information about the weather [2]. The objective of value affirmation is to ceaselessly work on the item or administration's quality, including increasing present expectations for fulfilling new quality guidelines by raising the general quality principles of the organization's item. It might likewise involve working on the cycle to work on the item or administration's quality [3].

Quality assurance is the efforts put by an organization or body to ensure that the services or products offered to the customers are of the best possible quality and meet the organization's standards [4]. The objective of quality assurance is to consistently improve the quality of the product or service, including improving the overall quality standards of the company's product by raising the general quality norms of the organization's item. Also, it can include improving the process to improve the quality of the product or service [5]. 
Customer service is a professional act of delighting customers by satisfying their needs by providing the best quality services on time. It should be an ongoing process and improves gradually [6].

In terms of the banking industry and banks such as ADIB, quality assurance plays an important role because the shared information should be of high quality. The bank can depend on it, and based on that, and shared information can take an effective and efficient decision.

\section{Information Sharing}

The robotized administration quality has improved since the web's appearance [7]. It has become mandatory for organizations to implement advanced technology to communicate effectively. Information sharing enables organizations to expedite their operations and bridge the services to reach the end customers through the internet, mobile banking, and ATMs. The operations quality has tremendously improved because it has provided ease in meeting the customers' daily needs [8]. As exchange level data is recorded and shared, the degree of control can be estimated by the quantity of exchanges. Thus, data sharing is a critical factor in expanding consumer loyalty [8].

\section{Quality Assurance}

In the banking sector, quality assurance is always measured in terms of products and services offered by the bank in a timely manner [9]. Quality assurance determines the customer level of satisfaction which they perceive through transactions. Since in the financial market, the competition is higher, so banks need to market their product offering to distinguish [3]. It comes possible only when how the product is packaged because customers expect a complete package including bills payment, a complete record of transactions and balance, bank statements on a monthly and quarterly basis, easy installments and insurance policies, etc. because the services of the bank are highly intangible in nature, therefore; it provides edge to compete assuring high-quality standards to serve customers better [5].

\section{Customer Service}

The financial business serves an assorted scope of customers, from people to organizations. Banks place a high need on consumer loyalty, which is intensely dependent on quality affirmation measures and information sharing. Because quality assurance guarantees the probability of increasing the number of satisfied customers [10], the resulting efforts would be enhancement of word of positive mouth attitude towards services incase if there is any kind 
of failure happens [11]. In the competitive era, the banks have understood that the way which is highly associated with satisfied customers, and it is possible only through information sharing and quality assurance [5].

\section{Information Sharing}

The exchange of data between technologies, people, and within an organization or outside organization is called information sharing [1]. The sharing information procedures and method of knowledge sharing in banking sectors provide a reliable source of connectivity with industries and stakeholders through relevant financial information of the sector. The information-sharing system also encourages managers to make quick decisions on time with significant proof of information to overcome the conflict that arises [12]. The banking system and procedures are the ongoing processes of operations where all banking departments are linked with financial departments of the government and private-public sectors. All relevant information could be circulating with specific time limits [3].

\section{Quality Assurance}

Quality assurance can be simply defined as efforts put by an organization or body to ensure that the services or products offered to the customers are of the best possible quality and meet the standards set by that organization [9]. The banking monetary area is quite possibly the most delicate and exact portions of the business, with no leeway in functional frameworks or client relations [13]. The little error in negative interaction creates the loss of stakeholders in the financial service organization. The little offense charges the customer is switching towards other banks or businesses elsewhere. Business organizations are investing their huge assets in employees training and development, especially the interaction with customers [2].

The need for training is for the employees to get involvement with customers, their interests, and the consistency of the relationship with the business. The banking sector also develops its employee's frontline management, especially with the interaction of the bank's customers [14]. Clients are the most important resource in the financial business,, and their satisfaction level is linked with the providing services and facilities from the banking procedures. Competitive policies attracting customers, face-to-face interaction, phone calls, internet banking, and other providing competitive services enhance the customer's satisfaction and retention towards the bank. The training of the employees in the banking system focuses on the soft skills of the interactions in which employees learn how to welcome customers with soft smiles and gestures [5].

Customer Service 
In simple terms, customer service is defined as a professional act of delighting customers through satisfying their needs by providing the best quality services in a timely manner [10]. It should be an ongoing process and improves gradually.

\section{Problem Statement}

Client care has gotten a great deal of consideration in the financial business. Be that as it may, most of these examinations zeroed in on a solitary country. Lasser et al. (2000), for instance, taken a gander at quality affirmation and fulfillment in private banking. Clients' impression of the nature of banks' administrations in the UAE were additionally looked at by Dash et al (2009). Obviously none of these investigations partitioned bank clients by sex, age, instruction, occupation, or geographic area (networks, regions, or locales). They just took a gander at what clients needed to say overall. However, a couple of studies zeroed in on a solitary country, like Caruana (2002), characterized bank clients by occupation, age, race, age, and instruction, none of them joined these factors (sexual orientation, age, schooling, and occupation) or gathered them by geographic area [15].

The flow study, specifically, adds to existing exploration on client care and quality affirmation. By suggesting the accompanying exploration conversation starters, it centers on the adequacy of vital assets in a brilliant policing setting:

RQ1: What are the various parts of policing quality affirmation that people in general sees and how would they influence client care?

RQ2: Which parts of shrewd policing greatest affect client support?

RQ3: Which aspects of quality assurance have the UAE banks demonstrated?

RQ4: What is the relationship between quality assurance dimensions and overall customer service?

RQ5: What factors have had the greatest impact on the level of quality assurance in UAE banks?

\section{Literature Review}

As indicated by [16], the information sharing system in the banking sector impacts quality assurance as it is one of the components that is handling and managing entire business banking operations within the timeline and accuracy of the data. The information-sharing procedure implementations in the banking sector help to operate functional properties of the financial sector develop risk management assessments on time. The information-sharing system in the banking sector integrates with information technology and digitalization that provides the interlinked relationship between information sharing and risk management. The 
entire operational activities in the banking system increase the financial performance and its positive impacts on risk management policies. The worldwide economy and banking area are changing their tasks with the digital time zone to provide effective and reliable information to the customers through direct connectivity with the banking linkages [17].

The information-sharing system of the banking sectors revitalized their functional strategies through digital applications and achieved desired goals. [6] stated that sharing information has a link with customer service improvement because the procedure of banking operations facilitates customers for their asset management resources and provides all detailed information of the account statements through digital applications to aware with their possessions. The banking sectors provide the security of the financial outcomes through information sharing systems to the industries and stakeholders. They know about their all kind of transactions and ongoing in-out processes [3]. The whole financial framework on the planet is interconnected, with monetary availabilities working on a worldwide scale. The entire banking system provides the information sharing system of the transactions, cash, debit, loan, interest, and other financial activities. The entire banking financial operations are covering through technology implementations in which all functional properties covering through sharing of information procedures and circulate all required information to the specific departments of the banks [18].

The sharing information system in the banking sector not only providing financial asset management services to the customers. In fact, it is a tool to create risk management policies and them aware of the coming threats in business functions. The information-sharing system in the banking sector helps banks for coming risks. It creates arrangements and methodologies to address the dangers that are associated inside the particular time limit with a precision of the data [19].

As indicated by [4], quality assurance is one of the new introducing terms in the business industry responsible for evaluating all that measures related to providing services to the customers to get their satisfaction towards them the products. The quality assurance system recommends quality assurance service standards to banking sectors to operate functional procedures for best business practices, especially in customer retention [2]. Apart from other business industries, the banking and financial business industry adopted high-quality digital information methods to assure the quality services of the business in which they are managing best practices of possible solutions through mobile banking, mobile wallets, online services through applications, and digital connectivity around the world to assure the quality services and products [5]. 
These quality confirmation administrations are given by the banking and monetary ventures as per worldwide sub-principles and guidelines. The quality assurance in business industries and banking financial development sectors focusing on providing persistent and high-quality services to their customers. The key component of the business productivity and customer acquisition depends on the banks' quality assurance services that improve the customer's retention and lead the profit. Quality assurance is also providing end-to-end monitoring and evaluating the process of functional activities of the banking sector and increases the productivity of the business [20]. The planned activities to ensure quality assurance make the possibilities of the profitable business outcomes through its implementation. The systematic strategies that create quality assurance for products help understand better the banking system's complex and challenging business. The quality assurance working implementations ensure the customer's expectancies towards their banks and get satisfactory outcomes through their efficient services [21].

As per [22], customers' expectations and achievement are the banking departments' core purpose. Several banking industries are circulating in the market and providing effective banking facilities to their customers through digital processes. The competitive advantage in banking sectors is high, which is why all banking sectors are improving their quality assurance activities for customer retention. Quality assurance aims to get customer satisfaction in all manners by providing in and out services of banking procedures and providing detailed information of the customers' asset management through efficient sources. Customer satisfaction relies on the product and services provided by the banks to their stakeholders [23].

Quality assurance is handling and catering to customers' processes, and it is a strategy to create brand position and acquisition in the market. The quality assurance service practices help to enhance the bank's reputation and its reliability in the market. The quality assurance services provide the operations' management and help create cost-effective controlling strategies for the banking sectors [24]. Quality assurance not only implementing to get customer retention and loyalty; it is developing the reduced cost of the goods and improve the level of good quality services. The quality assurance productivity in the banking sector creates profitable revenues for financial sectors [25].

As indicated by [7], the relationship of how quality assurance improves the quality of service through information sharing. The entire business operations of the banking sector are handling by the technology software and equipment, and the only method is to attain the customer is the employee's body language, an expression that presents the interest of the bank towards its customers. The improved banking system depends on its financial customers and 
banking sectors, emphasizing all technical skills involved to target the customers through product delivery and customer satisfaction interaction level through the bank staff. The customer services are started by entering the customer in branch and staff member would be ready to welcome them. The banking staff should acknowledge customers for their quire and provide easy and straight information of the process. The non-cooperative attitude of the staff member creates difficulty in understanding the procedures of banking information. The banking and finance department staff members should realize the customer interests and provide detailed sources of information most efficiently and accurately.

The staff member should be ready to provide truly care findings for customers' solutions and help them understand the technical banking information. The clear communication and personal skills of the banking and financial sector staff members help customers get knowledge in progressive ways. All banking information should be provided by explanations that could be easy to manage or understand for laymen. Several procedures are difficult to understand customers, especially in calculating the units and interest; the staff integration helps customers gain their interest to build their relationship through customer services [8].

\section{Research Gap and Contribution}

In the financial institutes, the banking sector is one of the major sectors with a longrange of customers. These customers expect service quality guaranteed by the banks, knowing that any loophole will cause switching behavior among the customers. Quality assurance and information sharing are the two major factors that influence customer service level because it has become mandatory to be competitive. Also, studies have shown that the bank's performance is highly dependent on the availability of information-sharing resources and quality assurance, which positively enhances the customer service base.

\section{UAE Banking Industry}

The objective of this exploration is to investigate the UAE's financial area and perceive that it is so ready to join the worldwide monetary framework. The little UAE banking area was served by 21 homegrown and 25 unfamiliar banks starting at 2005, demonstrating that the UAE banking area is exceptionally divided. Over $90 \%$ of complete homegrown resources are held by banks fused in Abu Dhabi and Dubai, with the absolute separated uniformly between Abu Dhabi and Dubai banks. Unfamiliar banks had restricted market access since they were just permitted to open up to eight branches all through the advanced financial activity (1980-2003) $[7]$.

Notwithstanding, laws were changed in 2003, and banks are presently allowed to open in excess of eight branches with unique consent. At the point when it came to opening a 
delegate office, notwithstanding, unfamiliar banks had no issues. There were 36 delegate workplaces across the emirates toward the finish of 2004. Subsequently, the UAE has been all around addressed by a different gathering of global banks. The customary financial area (barring Islamic banks) is administered by Federal Law 10, which was sanctioned in 1980, and Islamic banking is represented by Federal Law 6, which was ordered in 1985. The UAE banking area actually has a little Islamic financial area. Banks are restricted from charging a proper financing cost on stores or credits under Islamic financial laws. The establishment of Islamic banking is variable loan fees dependent on a benefit/misfortune sharing model. The Central Bank of the UAE was additionally settled under Federal Law 10, and it assumed control over the obligations of the Currency Board [16].

The bank's liabilities incorporate giving money related and monetary counsel to the public authority, giving cash, keeping up with gold and unfamiliar money holds, and fostering a credit strategy. The Central Bank is responsible for all administrative and administrative capacities. Since the UAE money is fixed to the US dollar, the national bank plays a restricted part in financial arrangement and loan fee control; in any case, it practices some money related and credit controls through the deal and acquisition of endorsements of stores. The national bank is associated with credit strategy plan and checking, just as monetary area management.

The national bank licenses all business banks joined in the UAE, and they are accordingly dependent upon the national bank's necessities and guidelines. The national bank ordered that all banks utilize International Accounting Standards (IAS) in 1998, and nearby banks were advised to build up clear corporate constructions in mid-1999. The UAE national bank likewise commands that banks keep a funding to-chance weighted-resources proportion of basically $10 \%$ consistently. All banks should be as indicated by UAE Central Bank guidelines. The difficulties that the UAE banking area is confronting are relied upon to endure for the following 18 to two years, with property showcases especially Dubai, proceeding to show a descending pattern in costs and rental yields. Project workers, building material providers, more modest engineers, and high-total assets people with openness to these areas will all endure because of the housing business sector's troubles.

Confronted with the monetary slump, various secretly held organizations, including family combinations, will rebuild their unique credits and advances with longer terms and lower loan fees. Different elements, for example, an increment in the proportion of nonperforming credits, could be set off by the rising number of rethought advances, which could caution market onlookers and bank valuators since they could adversely affect bank productivity. They should likewise be enlisted with the Federal Ministry of Economy and Trade 
as a "Shareholding Company" as characterized by the UAE Companies Law. (Joined Arab Emirates Central Bank, 2005).

\section{Research Model}

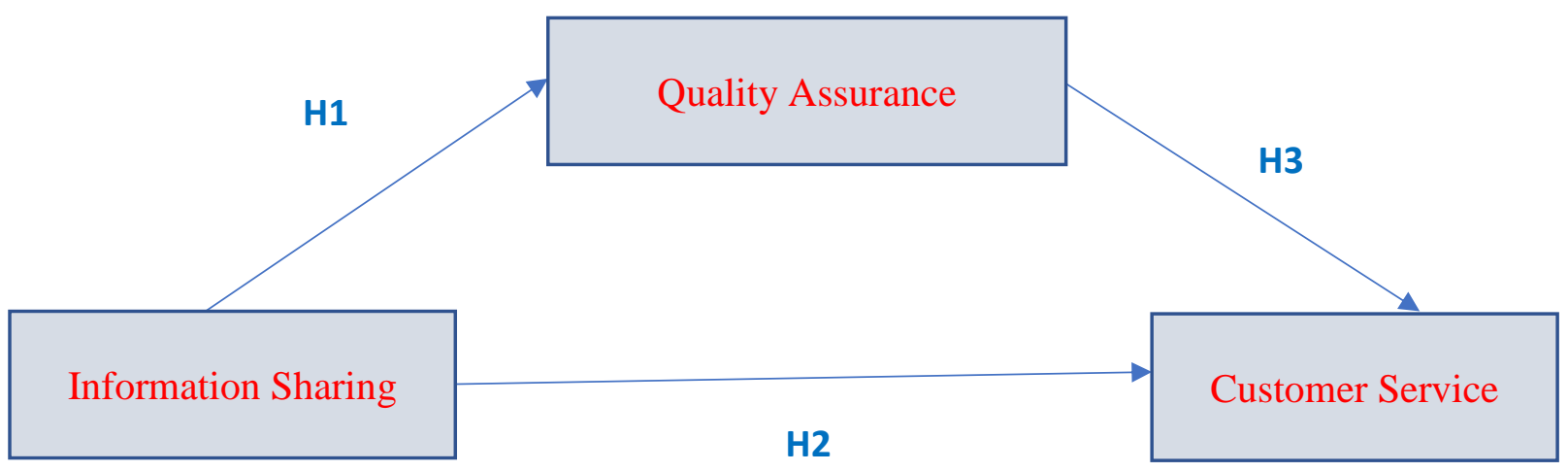

\section{Research Hypotheses}

Ho1: Information Sharing has no statistical impact on Quality Assurance in the Banking sector in Dubai at $(\alpha \leq 0.05)$

Ho2: Information Sharing has no statistical impact on Customer Service in Banking sector in Dubai at $(\alpha \leq 0.05)$ level.

Ho3: Quality Assurance has no statistical impact on Customer Service in the Banking sector in Dubai at $(\alpha \leq 0.05)$ level.

\section{Methodology and Research Design}

The proposed research methodology for this research report is the quantitative research design. We chose this research study because we were interested in collecting data and then analyzing it through hypothesis testing, which is very much likely to be done through statistical analysis. There were two sorts of inquiries in the study: (1) close ended inquiries, which required the respondent to browse a rundown of alternatives; and open-ended inquiries, which required the respondent to look over a rundown of choices. (2) scaled-reaction questions, which are shut finished inquiries with a rating scale to survey reaction alternatives (five-point Likert scale).

Every one of the four areas of the poll tended to at least one components of interest. The principal segment managed the socioeconomics of the association all in all. The subsequent segment focused on financial experience. The third segment zeroed in on assessing basic achievement factors and the criticality of all key achievement factors got from the writing. To take out predisposition and meet the rules needed by the logical techniques utilized, a huge 
and satisfactory example size was taken to guarantee that the information gathered would give a dependable premise to drawing deductions, making proposals, and supporting choices (Bryman and Cramer, 1996). Bryman and associates, then again, underline that the example size should be relative to the size of the populace. They likewise accept that the bigger the example size, the more exact the outcomes will be.

The option is to gather information from a couple of individuals in the gathering, with their reactions and qualities mirroring those of the gathering from which they were drawn. This strategy is significantly less costly, quicker, and simpler than surveying all individuals from a gathering, and it is broadly utilized in research. To accomplish the investigation's goals, quantitative examination philosophy was utilized. This is because of the way that this strategy can be utilized to create mathematical estimations and assessments of UAE banking reception. Study polls were utilized as a feature of the quantitative examination strategy to take into consideration the collection of the outcomes. On a 5-point likert scale, a survey was made. To quantify the factors and measurements of the exploration, strongly Disagree, Disagree, Neutral, Agree, and Strongly Agree were utilized.

\section{Population and Sample}

The population of the study is the banking sector of the UAE, including both private and public banks. There are 22 local and 30 foreign banks in the UAE. The sample is the banks in Dubai. A pilot study is required in light of the fact that it permits the analyst to get criticism from the members. Thusly, the scientist will actually want to decide whether the inquiries are hard to comprehend or then again in case they are one-sided or uncertain. Accordingly, respondents were approached to take part in a pilot study. Accordingly, all input was considered, and the poll was altered prior to being approved. The primary overview was dispersed to the planned populace after this stage was finished. The unit of analysis has been chosen by the managers working in the surveyed banks. We chose these banking sectors of their service quality, improving through gradual processes to ensure high customer services. The sampling technique for this study was convenient sampling which is the one type of nonrandom sampling technique. A proper 248 questionnaires were used for analysis.

\section{Data Collection}

There are many ways in data collection used by researchers to ensure high quality of research. There are two sources widely used for data collection.

Primary data source of collection: Surveys, observations, experiments, questionnaires, focus groups, interviews, and other primary data sources. 
Secondary data source of collection: While secondary data sources include books, journals, articles, web pages, blogs, and other secondary data sources.

In our research study, we applied both data sources for the compilation of the report. The secondary data source was used to collect data from the literature on the two independent variables information, sharing, and quality assurance. Literature was also reviewed on the dependent variable that is customer services at the banking sector.

A questionnaire survey design method was used to collect data. Questions were distributed among the Emirates NBD bank employees, and within two days, data was collected and prepared for analysis. The validity and reliability of the data was checked for final analysis.

\section{Reliability}

A reliability test is a stable and consistent result that can be produced through assessment tools over time. A study can be measured to be reliable if its result produced under comparable methodology, which means study tool can be applicable and repeatable over time. Hence, this research has used Cronbach's alpha tool, and the minimum reliability score to be accepted is 0.60 . As shown in below table 1, the reliability tool has been tested two variables (dependent and independent factors) and each variable and its dimensions through the measurement instrument. The reliability scores for Quality Assurance, Information Sharing, and Customer Service and its dimensions showed strongly significant, where Cronbach's alpha value was above (0.60) for all variables, which indicates that the items are internally consistent for each dimension.

Table 1 Cronbach's Alpha Coefficient for Study variables

\begin{tabular}{lc}
\hline Construct & Cronbach's Alpha \\
\hline Information Sharing & 0.761 \\
Quality Assurance & 0.872 \\
Customer Service & 0.783 \\
\hline
\end{tabular}

\section{Data Analysis}

The questionnaire of the study, which was distributed to 22 different bank branches in Fujairah, has been given to a number of academic and industrial experts to review. All comments have been taken into serious consideration and adapted before it distributed. All received questionnaires were checked for validity. A 220 valid Questionnaire and the data were investigated and examined through statistical and analytical package (SPSS) in order to test the relationship, and the impact of Information System Capabilities, Quality Assurance on Customer Service, descriptive statistic, correlation, and regression analysis, and ANOVA analysis were conducted to obtain the results.

\section{Descriptive Analysis}

Descriptive analysis and statistics are ways used for studying data and responsiveness of respondents about research variables that help in describing and summarizing the information into a meaningful. As showed in Table 2 the importance for each construct of the study indicating significant value, as all means and standard deviation refer to accepted values. 
Table 2 Descriptive Statistics for Study variables

\begin{tabular}{lccc}
\hline Construct & Mean & Std. Deviation & Variance \\
\hline Information Sharing & 3.751 & .88138 & .971 \\
Quality Assurance & 3.562 & .72636 & .784 \\
Customer Service & 3.749 & .91981 & .891 \\
\hline
\end{tabular}

\section{Hypotheses Testing}

Table 3 illustrates the results of Correlation, ANOVA, and Regression analysis to Quality Assurance in Information Sharing, and it described the significant relationship between Customer Service in Information Sharing where the correlation $(r)$ is $(0.588)$. The determinant coefficient is (0.346), which means that (0.346) changeability in the Quality Assurance is explained by the changeability in Information Sharing.

Table 3Correlation, ANOVA and Regression analysis to Quality Assurance in Information Sharing

\begin{tabular}{|c|c|c|c|c|c|c|c|c|c|}
\hline & $\mathrm{r}$ & $\mathrm{r}^{2}$ & $\mathrm{~F}$ & DF & Sig $^{*}$ & $\beta$ & & $t$ & Sig $^{*}$ \\
\hline $\begin{array}{c}\text { Quality } \\
\text { Assurance }\end{array}$ & .588 & .346 & $\begin{array}{c}26 . \\
368\end{array}$ & $\begin{array}{c}1 \\
247 \\
248\end{array}$ & .000 & $\begin{array}{l}\text { Information } \\
\text { Sharing }\end{array}$ & 0.621 & 4.016 & 0.000 \\
\hline
\end{tabular}

* level of significance $(\alpha \leq 0.05) * *$ Critical $t(d f / p)=1.64$

ANOVA analysis results indicate that there is impact of Information Sharing on Quality Assurance at beta is (0.621) confirmed by (t) is (4.016) and (f) is (26.368) and all values are significant at $(\alpha \leq 0.05)$ level. This evidence supports the first hypothesis which prove the impact of Information Sharing on Quality Assurance.

Table 4 illustrate the results of Correlation, ANOVA and Regression analysis to Customer Service in Information Sharing, it described significant relationship between Customer Service in Information Sharing where the correlation (r) is (0.549). The determinant coefficient is (0.301) which means that $(0.301)$ changeability in the Customer Service is explained by the changeability in Information Sharing.

Table 4Correlation, ANOVA and Regression analysis to Customer Service in Information Sharing

\begin{tabular}{|c|c|c|c|c|c|c|c|c|c|}
\hline & $r$ & $\mathrm{r}^{2}$ & $\bar{F}$ & DF & Sig* & $\beta$ & & $t$ & Sig* \\
\hline $\begin{array}{l}\text { Customer } \\
\text { Service }\end{array}$ & .549 & .301 & $\begin{array}{c}18 . \\
798\end{array}$ & $\begin{array}{c}1 \\
258 \\
259\end{array}$ & .000 & $\begin{array}{c}\text { Information } \\
\text { Sharing }\end{array}$ & 0.519 & 3.173 & 0.001 \\
\hline
\end{tabular}

$*$ level of significance $(\alpha \leq 0.05) * *$ Critical $t(d f / p)=1.64$

ANOVA analysis results indicate that there is an impact of Information Sharing on Customer Service at beta is (0.519) confirmed by (t) is (3.173) and (f) is (18.798) and all values are significant at $(\alpha \leq 0.05)$ level. This evidence supports the second hypothesis, which proves the impact of Information Sharing on Customer Service.

Table 5 illustrates the results of Correlation, ANOVA, and Regression analysis to Customer Service in Quality Assurance. It described a significant relationship between Customer Service in Information Sharing and Quality Assurance where the correlation (r) is (0.491). The determinant coefficient is $(0.241)$, which means that $(0.241)$ changeability in the Customer Service is explained by the changeability in Quality Assurance. 
Table 5Correlation, ANOVA and Regression analysis to Customer Service in Quality Assurance

\begin{tabular}{|c|c|c|c|c|c|c|c|c|c|}
\hline & $\mathrm{r}$ & $\mathrm{r}^{2}$ & $\bar{F}$ & DF & Sig* & $\bar{\beta}$ & & $\bar{t}$ & Sig $^{*}$ \\
\hline $\begin{array}{c}\text { Customer } \\
\text { Service }\end{array}$ & .491 & 241 & $\begin{array}{l}13 . \\
836\end{array}$ & $\begin{array}{c}1 \\
258 \\
259\end{array}$ & .000 & $\begin{array}{c}\text { Quality } \\
\text { Assurance }\end{array}$ & 0.348 & 2.856 & 0.002 \\
\hline
\end{tabular}

* level of significance $(\alpha \leq 0.05) * *$ Critical $t(d f / p)=1.64$

ANOVA analysis results indicate that there is an impact of Quality Assurance on Customer Service at beta is (0.348), confirmed by (t) is (2.856) and (f) is (13.836), and all values are significant at $(\alpha \leq 0.05)$ level. This evidence supports the third hypothesis, which proves the impact of Quality Assurance on Customer Service.

\section{Discussion of the Results}

The results showed that information sharing of the 5-stars hotels in Dubai lead to more quality assurance, coefficient of determination (0.346), correlation coefficient (0.588), ANOVA results $(\mathrm{t}=4.016)$, and regression results $(\mathrm{f}=26.368)$ are significant at (a£0.05), all prove the first alternative hypothesis which stated that Information sharing has a statistical impact on Quality assurance in 5-stars hotels in Dubai at (a£0.05).

Whereas the results refer that information sharing of the 5-stars hotels in Dubai lead to organizational Customer Service, coefficient of determination (0.301), correlation coefficient (0.549), ANOVA results $(\mathrm{t}=3.173)$, and regression results $(\mathrm{f}=18.798)$ are significant at (a£0.05), all prove the first alternative hypothesis which stated that Information sharing has no statistical impact on Customer Service in 5-stars hotels in Dubai at (a£0.05).

Moreover, The results indicated that quality assurance of the 5-stars hotels in Dubai leads to organizational Customer Service, coefficient of determination (0.241), correlation coefficient (0.491), ANOVA results $(\mathrm{t}=2.856)$, and regression results $(\mathrm{f}=13.836)$ are significant at (a£0.05), all prove the first alternative hypothesis which stated that Quality assurance has no statistical impact on Customer Service in 5-stars hotels in Dubai at (a£0.05).

Through questionnaire analysis, we have come to know that information sharing and quality assurance both go hand in hand because if the shared information is of quality only then, it will be possible for the organization's customer service department to serve the customers appropriately and to resolve the issue being faced by the customer. When it comes to a bank's customer service, the application of information sharing and quality assurance was made by ADIB as the bank faced several issues when it came to sharing information and the quality of shared information. There was no proper coordination between the IT department and customer service in the bank, which caused several issues. For example, when a customer complained to the customer service about any issue they faced with online banking or mobile 
banking, the customer service could not help immediately because of a lack of quality assurance in information sharing [26].

The customer service could not immediately solve the problem or get back to the customer in due time as the IT department and customer service was not on the same page. The information shared between these two departments was not of high quality or reliable, which confused both the departments and hence the problem. Therefore, ADIB bank applied quality assurance (QA) in information sharing to achieve healthy results between the customer service department and the IT department to solve or resolve the issues faced by customers [16].

The application of quality assurance in the information sharing between the departments in ADIB bank has improved the overall results of the customer service department as the department can now resolve customer's issues efficiently and quickly. If a customer is not receiving SMS for mobile banking services, the customer service department can immediately contact the IT department and take up the issue. A complaint number is assigned when a customer registers any issue being followed up by the customer service department with the IT department to expedite the matter. This is one of the examples through which quality assurance in information sharing has improved the customer service in ADIB bank.

\section{Conclusion and Recommendations}

Based on the above analysis and results, below are some recommendations:

The banking industry is evolving day by day, and so will be the technology. Therefore, the customer service department must be given periodic training to better understand the latest technology and to serve customers better. The banking sector needs to make sure that the their intra and inter related issues are resolved timely without any delays. The organizations only purpose is not to serve the customers but also to make sure that their employees are being accommodated in every possible way. 


\section{References}

[1] Y. M. Tai and C. F. Ho, "Effects of information sharing on customer relationship intention,” Ind. Manag. Data Syst., vol. 110, no. 9, pp. 1385-1401, 2010, doi: 10.1108/02635571011087446.

[2] H. Alzoubi and G. Ahmed, "Do TQM practices improve organisational success? A case study of electronics industry in the UAE," Int. J. Econ. Bus. Res., vol. 17, no. 4, pp. 459-472, 2019, doi: 10.1504/IJEBR.2019.099975.

[3] H. M. Alzoubi and R. Yanamandra, "Investigating the mediating role of information sharing strategy on agile supply chain," Uncertain Supply Chain Manag., vol. 8, no. 2 , pp. 273-284, 2020, doi: 10.5267/j.uscm.2019.12.004.

[4] M. A. Janahi and M. M. S. Al Mubarak, "The impact of customer service quality on customer satisfaction in Islamic banking,” J. Islam. Mark., vol. 8, no. 4, pp. 595-604, 2017, doi: 10.1108/JIMA-07-2015-0049.

[5] H. Alzoubi, M. Alshurideh, B. Al Kurdi, and M. Inairat, "Do perceived service value, quality, price fairness and service recovery shape customer satisfaction and delight? A practical study in the service telecommunication context," Uncertain Supply Chain Manag., vol. 8, no. 3, pp. 579-588, 2020, doi: 10.5267/j.uscm.2020.2.005.

[6] H. Alchalabi and A. Turan, "The Mediating Role of Perceived Value on The Relationship Between Service Quality, Destination Image, and Revisit Intention: Evidence From Umbul Ponggok, Klaten Indonesia,” vol. 9, no. 4, pp. 37-66, 2017, doi: 10.2991/icosop-16.2017.57.

[7] E. Tweneboah-Koduah and A. Yuty Duweh Farley, "Relationship between Customer Satisfaction and Customer Loyalty in the Retail Banking Sector of Ghana,” Int. J. Bus. Manag., vol. 11, no. 1, p. 249, 2015, doi: 10.5539/ijbm.v11n1p249.

[8] M. Alshurideh, A. Gasaymeh, G. Ahmed, H. Alzoubi, and B. Al Kurd, "Loyalty program effectiveness: Theoretical reviews and practical proofs," Uncertain Supply Chain Manag., vol. 8, no. 3, pp. 599-612, 2020, doi: 10.5267/j.uscm.2020.2.003.

[9] S. Revathi and A. Saranya, "Dimensions of Service Quality and Customer Satisfaction : Banking Sector,” Int. J. Adv. Sci. Res. Dev., vol. 03, no. 3, pp. 55-66, 2016.

[10] V. Yilmaz, E. Ari, and H. Gürbüz, "Investigating the relationship between service quality dimensions, customer satisfaction and loyalty in Turkish banking sector: An application of structural equation model,” Int. J. Bank Mark., vol. 36, no. 3, pp. 423- 
440, 2018, doi: 10.1108/IJBM-02-2017-0037.

[11] B. Al Kurdi, H. Elrehail, and H. M. Alzoubi, “THE INTERPLAY AMONG HRM PRACTICES , JOB SATISFACTION AND INTENTION TO LEAVE : AN EMPIRICAL INVESTIGATION,” no. August, 2021.

[12] H. M. Alzoubi, G. Ahmed, A. Al-Gasaymeh, and B. Al Kurdi, "Empirical study on sustainable supply chain strategies and its impact on competitive priorities: The mediating role of supply chain collaboration," Manag. Sci. Lett., vol. 10, no. 3, pp. 703-708, 2020, doi: 10.5267/j.ms1.2019.9.008.

[13] H. M. Alzoubi and R. Aziz, "Does emotional intelligence contribute to quality of strategic decisions? The mediating role of open innovation,” J. Open Innov. Technol. Mark. Complex., vol. 7, no. 2, 2021, doi: 10.3390/joitmc7020130.

[14] S. Joghee, H. M. Alzoubi, and A. R. Dubey, "Decisions effectiveness of FDI investment biases at real estate industry: Empirical evidence from Dubai smart city projects,” Int. J. Sci. Technol. Res., vol. 9, no. 3, pp. 3499-3503, 2020.

[15] A. Q. M. Alhamad, I. Akour, M. Alshurideh, A. Q. Al-Hamad, B. Al Kurdi, and H. Alzoubi, "Predicting the intention to use google glass: A comparative approach using machine learning models and PLS-SEM,” Int. J. Data Netw. Sci., vol. 5, no. 3, pp. 311-320, 2021, doi: 10.5267/j.ijdns.2021.6.002.

[16] H. Chahal and P. Bakshi, "Measurement of Intellectual Capital in the Indian Banking Sector," Vikalpa, vol. 41, no. 1, pp. 61-73, 2016, doi: 10.1177/0256090916629253.

[17] M. Alnuami, H. Alzoubi, D. Ajelat, and A. Alzoubi, “Toward Intelligent Organizations: An Empirical investigation of Learning Orientation's role in Technical Innovation,” Int. J. Innov. Learn., vol. 29, no. 2, pp. 207-221, 2021, [Online]. Available: https://www.inderscienceonline.com/doi/abs/10.1504/IJIL.2021.112996.

[18] T. M. Ghazal et al., "IoT for Smart Cities: Machine Learning Approaches in Smart Healthcare-A Review," Futur. Internet, vol. 13, no. 8, p. 218, 2021, doi: 10.3390/fi13080218.

[19] S. Hamadneh, O. Pederson, M. Alshurideh, B. Al Kurdi, and H. Alzoubi, “AN INVESTIGATION OF THE ROLE OF SUPPLY CHAIN VISIBILITY INTO THE AN INVESTIGATION OF THE ROLE OF SUPPLY CHAIN VISIBILITY INTO THE SCOTTISH BLOOD,” no. September, 2021.

[20] M. A. Alnuaimi, H. M. Alzoubi, and N. N. Alnazer, "Analysing the appropriate cognitive styles and its effect on strategic innovation in Jordanian universities," Int. J. Bus. Excell., vol. 13, no. 1, p. 127, 2017, doi: 10.1504/ijbex.2017.10006235. 
[21] Y. H. Akbar and A. Tracogna, "The sharing economy and the future of the hotel industry: Transaction cost theory and platform economics,” Int. J. Hosp. Manag., vol. 71, no. December 2017, pp. 91-101, 2018, doi: 10.1016/j.ijhm.2017.12.004.

[22] N. Nisha, "Exploring the dimensions of mobile banking service quality: Implications for the banking sector,” Int. J. Bus. Anal., vol. 3, no. 3, pp. 60-76, 2016, doi: 10.4018/IJBAN.2016070104.

[23] A. Toor, M. Hunain, T. Hussain, S. Ali, and A. Shahid, "The Impact of E-Banking on Customer Satisfaction: Evidence from Banking Sector of Pakistan,” J. Bus. Adm. Res., vol. 5, no. 2, 2016, doi: 10.5430/jbar.v5n2p27.

[24] A. Vargas-Sánchez et al., "Editorial Team Editor in Chief Editorial Board Advisory Board (Spanish Members) Advisory Board (Other European Members) Advisory Board (Members from the rest of the world)."

[25] S. K. Deepak Juneja, Shahzad Ahmad, “Adaptability of Total Quality,” Adapt. TQM to Serv. Sect., vol. 11, no. 02, pp. 93-98, 2011.

[26] S. M. Tseng, "Knowledge management capability, customer relationship management, and service quality,” J. Enterp. Inf. Manag., vol. 29, no. 2, pp. 202-221, 2016, doi: 10.1108/JEIM-04-2014-0042.

[26] Ghazal, T. M., Noreen, S., Said, R. A., Khan, M. A., Siddiqui, S. Y. et al. (2022). Energy Demand Forecasting Using Fused Machine Learning Approaches. Intelligent Automation \& Soft Computing, 31(1), 539-553.

[27] Ghazal, T.M. Internet of Things with Artificial Intelligence for Health Care Security. Arab J Sci Eng (2021). https://doi.org/10.1007/s13369-021-06083-8

[28] Aslam, M. S., Ghazal, T. M., Fatima, A., Said, R. A., Abbas, S. et al. (2021). EnergyEfficiency Model for Residential Buildings Using Supervised Machine Learning Algorithm. Intelligent Automation \& Soft Computing, 30(3), 881-888.

[29] Ghazal, T. M., Hussain, M. Z., Said, R. A., Nadeem, A., Hasan, M. K. et al. (2021). Performances of K-Means Clustering Algorithm with Different Distance Metrics. Intelligent Automation \& Soft Computing, 30(2), 735-742.

[30] Khan, Q., Ghazal, T. M., Abbas, S., Khan, W. A., Khan, M. A. et al. (2021). Modeling Habit Patterns Using Conditional Reflexes in Agency. Intelligent Automation \& Soft Computing, 30(2), 539-552.

[31] Rehman, E., Khan, M. A., Soomro, T. R., Taleb, N., Afifi, M. A., \& Ghazal, T. M. (2021). Using Blockchain to Ensure Trust between Donor Agencies and NGOs in Under-Developed Countries. Computers, 10(8), 98. doi:10.3390/computers10080098 
[32] Ghazal, T.M. Positioning of UAV Base Stations Using 5G and Beyond Networks for IoMT Applications. Arab J Sci Eng (2021). https://doi.org/10.1007/s13369-02105985-x

[33] Ghazal, T.M., Said, R.A. \& Taleb, N. Internet of vehicles and autonomous systems with AI for medical things. Soft Comput (2021). https://doi.org/10.1007/s00500-02106035-2

[34] Matloob, Faseeha \& Ghazal, Taher \& Taleb, Nasser \& Aftab, Shabib \& Ahmad, Munir \& Khan, Muhammad \& Abbas, Sagheer \& Soomro, Tariq. (2021). Software Defect Prediction Using Ensemble Learning: A Systematic Literature Review. IEEE Access. 9. 98754-98771. 10.1109/ACCESS.2021.3095559.

[35] T. M. Ghazal, M. Anam, M. K. Hasan, M. Hussain, M. S. Farooq et al., "Hep-pred: hepatitis c staging prediction using fine gaussian svm," Computers, Materials \& Continua, vol. 69, no.1, pp. 191-203, 2021.

[36] Ghazal, T. M., Kalra, D., \& Afifi, M. A. (2021). The Impact of Deploying the Internet of Things and How Will It Change Our Lives. Solid State Technology, 64(2).

[37] Taher M. Ghazal, Mohammed Kamrul Hasan, Rosilah Hasan, Shayla Islam, Siti Norul Huda Sheikh Abdullah, Mohammed A.M. Afifi, \& Deepak Karla. (2020). Security Vulnerabilities, Attachs, Threats and the Proposed Countermeasures for the Internet of Things Applications Solid State Technology, 63(1), 1566-1574. 